\title{
Pengaruh Motivasi Kerja Terhadap kinerja Pegawai di Badan Perpustakaan, Arsip dan Dokumentasi (BPAD) Propinsi Bengkulu
}

\author{
Darti Daryanti, Rohanda, Sukaesih \\ Perpustakaan Universitas Bengkulu \\ Prodi Ilmu Informasi dan Perpustakaan Fikom Unpad \\ Jl. Raya Bandung-Sumedang Km. 21 Jatinangor 45363
}

\begin{abstract}
Abstrak - Penelitian ini bertujuan untuk mengukur berapa besar pengaruh motivasi kerja intrinsik dan ektrinsik terhadap kinerja pegawai. Penelitian dilakukan di Badan Perpustakaan, Arsip dan Dokumentasi (BPAD) Propinsi Bengkulu, dengan sampel berjumlah 95 orang. Responden dalam penelitian ini adalah para pegawai termasuk pustakawan. Metode penelitian yang digunakan adalah deskriptif dengan pendekatan kuantitatif. Hasil penelitian diharapkan dapat berkontribusi terhadap peningkatan kinerja pegawai yang sesuai dengan standar ISO 11620 tahun 2008 tentang kinerja perpustakaan. Teknik pengumpulan data yang digunakan dalam penelitian ini adalah, angket atau kuesioner, observasi, wawancara, studi kepustakaan. Jenis angket yang digunakan dalam penelitian ini adalah angket tertutup dengan skala yang digunakan adalah skala Likert. Untuk mengukur pengaruh antar variabel penelitian, menggunakan Analisis Jalur (Path Analysis) dengan aplikasi program Lisrel 8.80 serta pengolahan data statistik data dengan bantuan program SPSS versi 15.0. Kesimpulan penelitian sebagai berikut, Pengaruh motivasi kerja intrinsik terhadap kinerja pegawai di BPAD Propinsi Bengkulu secara simultan terdapat pengaruh yang signifikan dengan ditunjukkan oleh hasil perhitungan $t_{\text {hitung }}>t_{\text {tabel, }}$, serta dengan koefisien jalur yang positif, artinya semakin tinggi motivasi kerja intrinsik maka semakin tinggi pula kinerja pegawai; Motivasi kerja ektrinsik terhadap kinerja pegawai di BPAD Propinsi Bengkulu secara simultan terdapat pengaruh positif, artinya semakin tinggi motivasi kerja ektrinsik maka akan semakin tinggi pula kinerja pegawai, serta dengan koefisien jalur yang ditunjukkan dengan hasil perhitungan $t_{\text {hitung }}>t_{\text {tabel, }}$ sehingga motivasi kerja ektrinsik berpengaruh secara signifikan terhadap kinerja pegawai.
\end{abstract}

Kata kunci: motivasi kerja, motivasi kerja intrinsik, motivasi kerja ektrinsik, kinerja pegawai, ISO 11620 tahun 2008.

Abstract - This study aimsto measure theinfluence of theintrinsicandextrinsicwork motivationon employee performance. The study was conductedinthe Library, ArchivesandDocumentation(BPAD) of Bengkulu province, withthe sampleamounted to95people. Respondentsin this study wereemployees, including librarians. The study used the descriptive methodwithquantitativeapproach. Results are expected tocontribute to improvingthe performance ofemployeesin accordance withthe ISO11620standardin 2008aboutthe performance ofthe library. Data collection techniquesusedin this study are questionnaires, observations, interviews, and literature study. The type ofquestionnaireused inthis studywas a questionnaireenclosedwiththe scaleused in theLikert scale. Tomeasure the effectbetweenthe studyvariables, usingpathanalysiswithLisrel8.80programapplicationsas well asstatisticaldata processingof datawith SPSSversion 15.0. The research concluded: effect of intrinsic work motivation on employee performance in BPAD Bengkulu simultaneously showed a significant difference shown by the results of the calculation of $t>t$ table, as well as the positive path coefficient, meaning that the higher intrinsic work motivation, the higher the employee performance; extrinsic work motivation on employee performance in BPAD Bengkulu simultaneously showed positive, meaning that the higher the extrinsic work motivation, the higher will be the employee's performance, as well as the path coefficient indicated by the calculation of $t>t$ table, so the extrinsic work motivation has significant influence on employee performance.

\section{Pendahuluan}

Organisasi merupakan suatu kelompok individu yang diorganisasikan dalam struktur tertentu untuk mencapai tujuan tertentu. Untuk menjalankan suatu organisasi diperlukan adanya manusia yang mengelola dan bergerak dalam orgaanisasi itu yaitu yang sering disebut-sebut sebagai sumber daya manusia. Sumber daya manusia merupakan salah satu unsur yang penting dan akan saling berinteraksi serta bergantung satu dengan yang lain. Seiring dengan hal ini ada pendapat yang mengemukakan apa yang dimaksud dengan sumber daya manusia. Sumber Daya Manusia adalah seorang yang siap, mau dan mampu memberi sumbangan usaha pencapaian tujuan organisasi. (Riva'I 2008, hal 6). 
Seiring dengan hal ini, suatu unit kerja yang berfungsi sebagai penyebarluas informasi, perpustakaan sebagai suatu organisasi juga memerlukan peran SDM didalamnya. Komponen yang paling penting dalam suatu oragnisasi tergantung dari ketersediaan SDM. SDM harus selalu bekerja secara produktif, kreatif, inovatif dan profesional dalam memnuhi tujuan dari organisasi. Perpustakaan sebagai organisasi yang bergerak di bidang informasi juga membutuhkan dukungan dari SDM yang memiliki kemampuan yang handal, memiliki kemampuan dan keterampilan yang tinggi, menyadari akan perannya atau pergaulan dengan rekan kerja maupun dengan pihak pimpinan. Produktivitas dalam menjalankan suatu pekerjaan tergantung dengan pimpinan tentang bagaimana seorang pimpinan memotivasi bawahannya. Suatu organisasi dimana didalamnya terjalin hubungan yang baik itu antara atasan, bawahan, maupun rekan kerja dalam organisasi itu sendiri.

Motivasi merupakan istilah yang sering kali disinggung oleh atasan sebagai pemimpin suatu organisasi baik itu secara terbuka maupun secara pribadi atau perorangan. Motivasi memang erat sekali kaitannya dengan kepemimpinan. Merupakan suatu hal yang berat bagi pimpinan yakni bagaimana memotivasi anggota organisasi atau bawahannya. Begitu juga dengan individunya, harus mengetahui bagaimana memotivasi diri sendiri dalam pekerjaan. Biasanya seorang pegawai yang lesu dan loyo dalam melakukan pekerjaan maka ini menjadi suatu pertanyaan dan masalah yang harus dicari penyelesaiannya. Suatu organisasi selalu mendambakan keadaan dimana pegawainya memiliki kinerja yang tinggi.

Sebagaimana telah kita ketahui bahwa ada pandangan tentang motivasi kerja yang dikemukakan oleh Ernest J. McCormick (1985:268) mengemukakan bahwa "Work motivation is defined as conditions which influence the arousal, direction, and maintenance of behaviors relevant in work settings". (Motivasi kerja didefinisikan sebagai kondisi yang berpengaruh membangkitkan, mengarahkan dan memelihara perilaku yang berhubungan dengan lingkungan kerja). (Mangkunegara 2001, hal. 94). Seiring dengan pendapat tersebut ada sebuah pendapat tentang teori motivasi itu sendiri
Menurut Frederick Herzberg (1966) dalam Hasibuan (2003:108), motivasi yang ideal yang dapat merangsang usaha adalah "peluang untuk melaksanakan tugas yang lebih membutuhkan keahlian dan peluang untuk mengembangkan kemampuan". Herzberg menjelaskan bahwa faktor-faktor atau situasi yang merupakan sumber kepuasan kerja dinamakan satisfiers atau perasaan puas yang berkaitan langsung dengan pekerjaan yang dilakukan. Sedangkan faktor-faktor yang menjadi sumber ketidakpuasan disebut dissatisfiers atau hygiene factors. Atau sering disebut Two Factor Motivation Theory. Konsep ini antara lain:

\section{Isi (Content=Satisfiers $)$ Pekerjaan}

a. Prestasi (Achievement)

b. Pengakuan (Recognition)

c. Pekerjaan itu sendiri (The work it self)

d. Pengembangan Potensi Individu (Advancement)

Rangkaian ini melukiskan hubungan seseorang dengan apa yang dikerjakannya (job-content) yakni kandungan kerja pada tugasnya. Hal ini juga sering disebut motivasi intrinsik.

2. Faktor Higienis (Demotivasi=Dissatisfiers)
a. Gaji atau upah (Wages or Salaries)
b. Kondisi Kerja (Working Condition)
c. Kebijaksanaan dan Administrasi Perusahaan (Company Policy and Administrastion)
d. Hubungan Antarpribadi (Interpersonal Relation)

e. Kualitas Supervisi (Quality Supervisor). Faktor higienis sering disebut motivasi ekstrinsik. (Hasibuan 2003, hal.110).

Berkaitan dengan pendapat di atas, jelas sekali bahwa motivasi juga ikut dipengaruhi sedikit banyak oleh individu itu sendiri dan faktor pimpinan. Pegawai yang dalam hal ini yang bekerja sebagai individu penggerak roda organisasi khususnya perpustakaan, memiliki motivasi yang tinggi yang diharapkan dari organisasi. Apabila motivasi ini tidak timbul dari diri pegawai maka akan mengakibatkan organisasi atau perpustakaan menjadi stagnan. Hal ini nantinya akan berpengaruh buruk terhadap penurunan kinerja dari pegawai bahkan organisasi itu sendiri. 
Keberhasilan suatu organisasi dapat ditentukan oleh hasil kerja pegawainya atau dengan kata lain peningkatan kinerja suatu organisasi dapat dilihat dari bagaimana aktivitas para pegawai dalam menghasilkan output dari pekerjaan atau prestasi kerjanya. Berkaitan dengan organisasi, apabila kondisi dari suatu organisasi kurang baik, maka akan berpengaruh terhadap efektifitas kegiatan organisasi, terlebih lagi apabila kondisi ini berasal dari motivasi pegawai, maka hal ini akan berpengaruh terhadap pencapaian tujuan dari organisasi itu sendiri sehingga kinerja pegawai dan kinerja organisasipun akan berkurang. Sebagaimana yang telah dikemukakan menurut Kementerian Negara Pendayagunaan Aparatur Negara dalam Saleh (2013, hal.2), "Kinerja adalah unjuk kerja dan prestasi kerja atau hasil kerja yang diwujudkan dalam melakukan suatu kegiatan atau program atau mencapai tujuan dan sasaran tertentu serta upaya dalam mencapai hasil dan capaiannya (accomplishment)".

Sesuai dengan hal ini, kinerja dapat dipengaruhi diantaranya motivasi, pendidikan, pelatihan, kemampuan, pengetahuan umum, pengetahuan teknis, pengalaman kerja, latar belakang budaya, iklim organisasi, penerangan, suhu udara, gaji/upah dan lain-lain. Dari beberapa faktor ini, motivasi merupakan faktor yang sangat penting dalam rangka menciptakan kinerja yang baik bagi pegawai. Sikap mau bekerja keras dan antusias timbul karena adanya motivasi dari pegawai itu sendiri. Apabila motivasi tidak muncul dari diri pegawai maka akan mengakibatkan kekecewaan dari banyak pihak terutama bagi organisasi itu sendiri sehingga tujuan organisasi yang diharapkan tidak akan tercapai.

Badan Perpustakaan, Arsip dan Dokumentasi (BPAD) Propinsi Bengkulu yang merupakan sarana penunjang dalam pendidikan dan sarana penyedia informasi bagi masyarakat yang berasal dari berbagai elemen mulai dari sekolah dasar sampai perguruan tinggi serta masyarakat umum yang ada di propinsi Bengkulu. BPAD Propinsi Bengkulu memiliki tujuan utama yaitu memberikan akses dan kebutuhan informasi secara cepat, tepat dan up to date kepada pengguna. BPAD Propinsi Bengkulu memiliki visi dan misi dalam pencapaian tujuannya.Visi dari
BPAD Propinsi Bengkulu adalah "Gemar Membaca dan Tertib Arsip 2015”. Misi dari BPAD Propinsi Bengkulu ada 5 yaitu (1) Membina secara teknis dengan kemitraan semua jenis perpustakaan, arsip dan dokumentasi propinsi Bengkulu; (2) Melaksanakan layanan informasi perpustakaan, arsip dan dokumentasi secara prima; (3) Menyiapkan dan menyelenggarakan perpustakaan, arsip dan dokumentasi sebagai rujukan dan penelitian; (4) Melestarikan bahan pustaka, kearsipan dan dokumentasi sebagai warisan budaya bangsa; (5) Mengelola, mendayagunakan dan mengembangkan sumber daya yang ada termasuk didalamnya bahan pustaka, kearsipan dan dokumentasi. (BPAD Propinsi Bengkulu, 2012). Pengembangan perpustakaan yang mampu bersinergi dan berkualitas, perpustakaan harus memiliki sumber daya manusia yang profesional, yang memiliki semangat dan etos kerja yang tinggi, jujur, berdedikasi, serta mampu dan memiliki kemauan dalam mengembangkan keilmuannya.

BPAD propinsi Bengkulu sebagai organisasi yang bergerak dalam bidang informasi yang didalamnya terdapat sumber daya manusia sebagai individu maupun yang kelompok yang bekerja sama untuk mencapai tujuan organisasi. Kebutuhan informasi yang up to date yang dibutuhkan oleh pengguna memiliki pemicu bagi BPAD Propinsi Bengkulu untuk tetap menjaga informasi atau koleksi yang mereka miliki, namun disamping itu juga dilakukan bagaimana caranya mereka meningkatkan kinerja para pegawai untuk dapat menyiapkan dan memberikan informasi kepada pengguna. Berhubungan dengan hal tersebut, BPAD Propinsi Bengkulu memiliki sumber daya manusia keseluruhan berjumlah kurang lebih 95 orang dengan pustakawan berjumlah 25 orang. Dengan jumlah pustakawan yang ada, memang masih belum sebanding dengan jumlah staf yang ada. Namun dengan jumlah pustakawan yang ada saat ini, perpustakaan diharapkan tetap dapat melakukan fungsi dan tujuannya serta dapat terjalin kerja sama yang baik antar pustakawan dan pegawai serta dapat menciptakan motivasi kerja yang akhirnya dapat meningkatkan kinerja bagi pegawai di lingkungan BPAD propinsi Bengkulu. 
Latar belakang pemikiran diatas melandasi penulis untuk melakukan penelitian yang lebih mendalam mengenai "Pengaruh Motivasi Kerja Terhadap Kinerja Pegawai di Badan Perpustakaan, Arsip dan Dokumnetasi (BPAD) Propinsi Bengkulu".

\section{Tujuan Penelitian}

Berdasarkan maksud penelitian tersebut maka ditetapkan tujuan penelitian ini adalah untuk mengetahui:

1. Mengukur berapa besar pengaruh motivasi kerja intrinsik terhadap kinerja pegawai di BPAD Propinsi Bengkulu.

2. Mengukur berapa besar pengaruh motivasi kerja ekstrinsik terhadap kinerja pegawai di BPAD Propinsi Bengkulu.

\section{Metode Penelitian}

Metode yang digunakan dalam penelitian ini adalah metode survei eksplanatori (survey explanatory) yaitu suatu metode survei yang bertujuan untuk menguji hipotesis (Rusidi, 1990), dengan pendekatan kuantitatif. Sifat penelitian adalah verifikasi dan deskriptif analisis.

Adapun variabel bebas $(\mathrm{X})$ dalam penelitian ini adalah Motivasi, $\mathrm{X}_{1}$ Isi (content=satisfiers) pekerjaan/motivasi intrinsik, $\mathrm{X}_{2}$ Higienis (demotivasi=dissatisfiers)/motivasi ekstrinsik. Sedangkan variabel terikatnya (Y) adalah Kinerja Pegawai. Operasional variabel menggunakan alat ukut yaitu kuesioner dengan lima puluh lima pernyataan dari variabel bebas dan variabel terikat. Populasi penelitian ini meliputi seluruh pegawai di BPAD Propinsi Bengkulu, termasuk didalamnya pustakawan dengan jumlah kurang lebih 95 orang. Dalam penarikan sampel digunakan metode Sampling Jenuh, sebutan lain adalah Total Sampling. "Sampling Jenuh adalah teknik penentuan sampel bila semua anggota populasi digunakan sebagai sampel dan dikenal juga dengan istilah sensus".

Teknik pengumpulan data yang digunakan dalam penelitian ini adalah, (1) Angket atau kuesioner (questionnaires), (2) Observasi, (3) Wawancara, (4) Studi Kepustakaan. Jenis angket yang digunakan dalam penelitian ini adalah angket tertutup. Skala yang digunakan dalam angket ini menggunakan skala Likert.

Analisis data penelitian ini menggunakan

Path Analysis, dimana disyaratkan harus memenuhi syarat langkah uji validitas dan uji reliabilitas. Analisis Jalur (Path Analysis) menurut Al-Rasyid (1977) dalam Sitepu (1994:23) merupakan "analisis dengan tujuan menerangkan akibat langsung dan tidak langsung seperangkat variabel, sebagai variabel penyebab (eksogenus), terhadap seperangkat variabel lainnya yang merupakan variabel akibat (endogenus)".

\section{Hasil dan Pembahasan}

Berdasarkan hasil analisa data yang telah dilakukan, peneliti menginterpretasikan sebagai berikut:

\section{Analisis Jalur dan Pengujian Hipotesis}

Untuk mengetahui pengaruh motivasi kerja secara simultan maupun parsial berpengaruh terhadap kinerja pegawai di BPAD Propinsi Bengkulu digunakan analisis jalur. Berikut adalah model pengaruh motivasi kerja terhadap kinerja pegawai dengan struktur utama dan substruktur pengaruh motivasi kerja terhadap penjabaran kinerja. Komponen persamaan akhir hasil analisis jalur yang menyatakan hubungan antara variabel motivasi kerja (intrinsik dan ektrinsik) terhadap kinerja pegawai, model persamaan analisis jalur yang terbentuk dinyatakan sebagai berikut:

\section{Tabel 1 Besarnya Koefisien Jalur}

\begin{tabular}{|l|l|}
\hline Variabel & $\begin{array}{l}\text { Koefisien } \\
\text { Jalur }\end{array}$ \\
\hline $\begin{array}{l}\text { Motivasi kerja intrinsik terhadap } \\
\text { kinerja pegawai }\end{array}$ & 0,58 \\
\hline $\begin{array}{l}\text { Motivasi kerja ektrinsik terhadap } \\
\text { kinerja pegawai }\end{array}$ & 0,35 \\
\hline
\end{tabular}

Sumber tabel di atas, dapat dibuatkan dalam diagram jalur sebagai berikut:

\section{Gambar 1 Diagram Jalur Pengaruh MotivasiKerjaTerhadap Kinerja Pegawai di BPAD Propinsi Bengkulu}

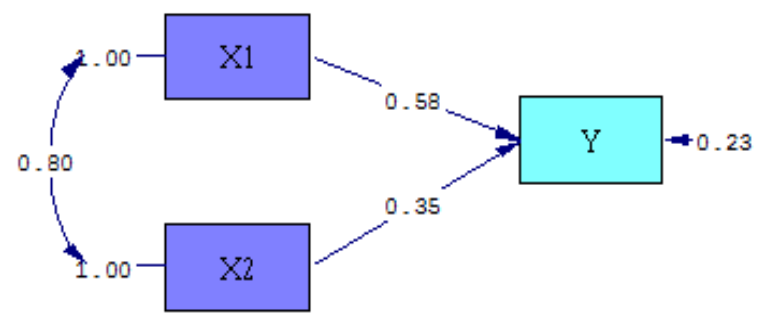

Untuk pengujian hipotesis secara simultan dan parsial, Uji $\mathrm{F}$ bertujuan untuk melihat signifikan tidaknya pengaruh variabel bebas yaitu motivasi kerja (motivasi kerja intrinsik dan motivasi kerja ekstrinsik) (X) secara parsial dan simultan 
terhadap variabel terikat yaitu kinerja pegawai (Y) di BPAD Propinsi Bengkulu.

Pengujian Secara Individu (Parsial) dari Stuktur Pengaruh Motivasi Kerja Terhadap Kinerja Pegawai di BPAD

Berdasarkan hasil perhitungan analisis jalur diperoleh besaran sebagai berikut:

Tabel 2 Besar Pengaruh Motivasi Kerja Intrinsik $\left(\mathrm{X}_{1}\right)$ terhadap Kinerja Pegawai $(Y)$

\begin{tabular}{|l|l|l|l|}
\hline Variabel & Pengaruh & $\mathbf{r}^{2}$ & $\mathbf{\%}$ \\
\hline \multirow{3}{*}{$\mathrm{X}_{1}$} & Pengaruh langsung ke Y & 0,333 & $33,27 \%$ \\
\cline { 2 - 4 } & $\begin{array}{l}\text { Pengaruh tidak langsung } \\
\text { melalui } \mathrm{X}_{2} \text { ke Y }\end{array}$ & 0,161 & $16,06 \%$ \\
\cline { 2 - 4 } & Total & 0,493 & $49,33 \%$ \\
\hline
\end{tabular}

Sumber: Pengolahan Data 2014

Pengaruh secara langsung antara variabel motivasi intrinsik terhadap kinerja pegawai sebesar $33,27 \%$. Pengaruh tidak langsung antara motivasi intrinsik terhadap kinerja pegawai melalui motivasi ektrinsik sebesar $16,06 \%$. Total pengaruh variabel motivasi intrinsik baik secara langsung maupun tidak langsung terhadap kinerja pegawai $=33,27 \%+16,06 \%=49,33 \%$.

Berikut adalah hipotesis ang diajukan untuk melihat pengaruh motivasi intrinsik terhadap kinerja pegawai:

$H_{0}$ : artinya tidak adanya pengaruh yang signifikan dari motivasi kerja intrinsik terhadap kinerja pegawai

$H_{1}$ : artinya adanya pengaruh yang signifikan dari motivasi kerja intrinsik terhadap kinerja pegawai.

Tabel 3 Uji t Pengaruh Motivasi Kerja Intrinsik $\left(X_{1}\right)$ terhadap Kinerja Pegawai $(Y)$

\begin{tabular}{|c|c|c|c|c|}
\hline $\begin{array}{l}\text { Variabel } \\
\text { Laten } \\
\text { Eksogen } \\
\overrightarrow{\text { Endogen }}\end{array}$ & $\begin{array}{l}\text { Koefisien } \\
\text { Jalur }\end{array}$ & $\begin{array}{l}\mathbf{t} \\
\text { hitung }\end{array}$ & $\mathbf{t}_{\text {tabel }}$ & Keterangan \\
\hline $\begin{array}{l}\text { Motivasi } \\
\text { Kerja } \\
\text { Intrinsik } \\
\text { terhadap } \\
\text { Kinerja } \\
\text { Pegawai }\end{array}$ & 0,58 & 6,93 & 1,98 & Signifikan \\
\hline
\end{tabular}

Sumber: Pengolahan Data 2014

Kriteria pengujian hipotesis: tolak Ho jika

$t_{\text {hitung }}>t_{\text {tabel }}$ atau $t_{\text {hitung }}<-t_{\text {tabel }}$

Dari hasil penelitian terlihat bahwa

besarnya pengaruh langsung antara "motivasi kerja intrinsik" $\left(\mathrm{X}_{1}\right)$ terhadap "kinerja pegawai"
(Y) adalah 0,58. Ini berarti motivasi kerja intrinsik yang meliputi indikator prestasi, pengakuan, pekerjaan itu sendiri, pengembangan potensi individu di BPAD Propinsi Bengkulu memiliki pengaruh yang tinggi dan positif terhadap peningkatan kinerja pegawai. Untuk memacu motivasi kerja intrinsik dari pegawai ini tentu saja dibutuhkan peran pimpinan sebagai manajer di perpustakaan yang senantiasa memperhatikan para pegawainya baik itu dari segi prestasi, pengakuan, pekerjaan, pengembangan potensi individu.

Kebutuhan akan prestasi, yakni pemberian dorongan pada pegawai untuk memiliki dan meningkatkan prestasi yang lebih tinggi. Berkaitan dengan hal ini, ada pendapat yang mengatakan tentang teori kebutuhan untuk mencapai prestasi dari McCleland yang disebut juga dengan istilah "McCleland's Need For Achievement Theory". Inti dari teori ini menyatakan bahwa pemahaman akan motivasi akan semakin mendalam apabila disadari bahwa setiap orang mempunyai tiga jenis kebutuhan, yaitu: "Need for Avhievement" (yang sering dinyatakan dengan rumus nAch.), "Need for Power" (nPo.), dan "Need for Affiliation" (nAff.). (Siagian, 2004:167).

Kebutuhan ini tercermin dalam rasa tangunggjawab yang tinggi terhadap tugas. Pegawai biasanya memiliki keinginan yang kuat untuk mendapatkan tanggapan dari pekerjaan yang dilakukannya. Disamping prestasi kerja yang meningkat, pegawai juga akan terpacu untuk bekerja secara lebih optimal. Selain indikator prestasi, indikator lain dari motivasi kerja intrinsik seperti akan ada pengakuan serta penghargaan dan pujian terhadap prestasi atas pekerjaan yang dilakukan, begitu juga dengan pekerjaan itu sendiri yang memberikan kebanggaan tersendiri bagi pegawai dalam pelaksanaan tugasnya dan melakukan pekerjaan dengan penuh tanggungjawab. Dengan demikian, apabila pegawai sudah memunculkan prestasinya dalam bekerja, tentu saja pihak pimpinan atau manajer akan memebrikan pendidikan dan pelatihan pada para pegawai sehingga di akhir penilaian pekerjaannya, pegawai memperoleh nilai angka kredit yang tinggi dan selanjutnya akan dipromosikan jabatannya di lembaga.

Dalam beberapa teori motivasi dijelaskan bahwa motivasi kerja intrinsik seperti yang telah dikemukakan di atas dan dihubungkan dengan 
hasil uji yang telah diteliti, maka motivasi kerja intrinsik berpengaruh signifikan terhadap kinerja pegawai di BPAD Propinsi Bengkulu dengan hasil $t_{\text {hitung }}$ lebih besar dari $t_{\text {tabel }}$ dengan $\alpha=0,05\left(t_{\text {hitung }}\right.$ $\left.6,93>t_{\text {tabel }} 1,98\right)$. Dari koefisien jalur yang menunjukkan hasil yang positif $(0,58)$ yang menerangkan bahwa semakin tinggi motivasi kerja intrinsik maka akan semakin tinggi pula kinerja pegawai di BPAD Propinsi Bengkulu.

\section{Uji Pengaruh Motivasi Kerja Ektrinsik} Terhadap Kinerja Pegawai

Berdasarkan hasil perhitungan analisis jalur diperoleh besaran sebagai berikut:

Besar Pengaruh Motivasi Ektrinsik $\left(\mathbf{X}_{2}\right)$ terhadap Kinerja Pegawai (Y)

\begin{tabular}{|l|l|l|l|}
\hline Variabel & Pengaruh & $\mathbf{r}^{\mathbf{2}}$ & $\mathbf{\%}$ \\
\hline \multirow{4}{*}{$\mathrm{X}_{2}$} & Pengaruh langsung ke Y & 0,12 & 12,01 \\
\cline { 2 - 4 } & & 0 & $\%$ \\
\cline { 2 - 4 } & Pengaruh tidak langsung melalui & 0,16 & 16,06 \\
& $\mathrm{X}_{1}$ ke Y & 1 & $\%$ \\
\cline { 2 - 4 } & \multirow{2}{*}{ Total } & 0,28 & 28,07 \\
& & 1 & $\%$ \\
\hline
\end{tabular}

Sumber: Pengolahan Data 2014

Pengaruh secara langsung antara variabel motivasi kerja ektrinsik terhadap kinerja pegawai sebesar $12,01 \%$. Pengaruh tidak langsung antara motivasi kerja ektrinsik terhadap kinerja pegawai melalui motivasi intrinsik sebesar $16,06 \%$. Total pengaruh variabel motivasi kerja ektrinsik baik secara langsung maupun tidak langsung terhadap kinerja pegawai $=12,01 \%+16,06 \%=28,07 \%$.

Berikut adalah hipotesis ang diajukan untuk melihat pengaruh motivasi ektrinsik terhadap kinerja pegawai:

$H_{0}$ : artinya tidak adanya pengaruh yang signifikan dari motivasi kerja ektrinsik terhadap kinerja pegawai

$H_{1}$ : artinya adanya pengaruh yang signifikan dari motivasi kerja ektrinsik terhadap kinerja pegawai

Hasil perhitungan dengan menggunakan SPSS dan LISREL adalah sebagai berikut:

Uji t Pengaruh Motivasi Kerja Ektrinsik $\left(\mathrm{X}_{2}\right)$ terhadap Kinerja Pegawai (Y)

\begin{tabular}{|c|c|c|c|c|}
\hline $\begin{array}{l}\text { Variabel } \\
\text { Laten } \\
\text { Eksogen } \\
\rightarrow \\
\text { Endogen }\end{array}$ & $\begin{array}{l}\text { Koefisien } \\
\text { Jalur }\end{array}$ & $\begin{array}{l}\mathbf{t} \\
\text { hitung }\end{array}$ & $\begin{array}{l}\mathrm{t} \\
\text { tabel }\end{array}$ & Keterangan \\
\hline $\begin{array}{l}\text { Motivasi } \\
\text { Kerja }\end{array}$ & 0,35 & 4,16 & 1,98 & Signifikan \\
\hline
\end{tabular}

\begin{tabular}{|l|l|l|l|}
\hline $\begin{array}{l}\text { Ektrinsik } \\
\text { terhadap } \\
\text { Kinerja } \\
\text { Pegawai }\end{array}$ & & & \\
\hline
\end{tabular}

Kriteria pengujian hipotesis:

tolak Ho jika $t_{\text {hitung }}>t_{\text {tabel }}$ atau $t_{\text {hitung }}<-t_{\text {tabel }}$

Dari hasil penelitian terlihat bahwa besarnya pengaruh langsung antara "motivasi kerja ektrinsik" $\left(\mathrm{X}_{2}\right)$ terhadap "kinerja pegawai" (Y) adalah 0,35. Ini berarti motivasi kerja ektrinsik yang meliputi indikator gaji/upah, kondisi kerja, kebijaksanaan dan administrasi perpustakaan, hubungan antar pribadi dan kualitas supervisi memiliki pengaruh tinggi dan positif terhadap peningkatan kinerja pegawai.

Motivasi kerja ektrinsik ini dapat ditingkatkan tentu saja dibutuhkan peran pimpinan di dalamnya, selain itu juga dipengaruhi oleh fasilitas pekerjaan dan kondisi lingkungan sekitar tempat bekerja. Seperti yang dikemukakan oleh Herzberg dalam Hasibuan (2003:110), yang mengatakan "bahwa motivasi juga dipengaruhi oleh faktor higienis. Faktor higienis (Demotivasi=Dissatisfiers) dari motivasi adalah sebagai berikut: gaji atau upah, kondisi kerja, kebijaksanaan dan administrasi perusahaan, hubungan antar pribadi dan kualitas supervisi". Berdasarkan penjelasan dari teori ini, menjelaskan bahwa seseorang bekerja tidak sekedar mencari nafkah namun sebagai tempat untuk memuaskan diri dan kebutuhannya bagaimanapun kebutuhan itu dikategorikan.

Motivasi kerja ektrinsik yang meliputi gaji/upah yang diberikan kepada pegawai dan tunjangan lain bisa diperoleh dari gaji pokok pegawai dan tunjangan fungsional pustakawan bagi yang berprofesi sebagai pustakawan, begitu juga staf yang diberikan tunjangan struktural baik itu yang memiliki jabatan maupun yang non jabatan di BPAD Propinsi Bengkulu. Berkenaan dengan tunjangan fungsional pustakawan, ada peraturan yang mengatur tentang tunjangan fungsional pustakawan yang mengalami kenaikan pada tanggal 12 Novemper 2013, yakni Peraturan Presiden (PP) No.71 Tahun 2013 tentang Tunjangan Fungsional Pustakawan. Besarnya tunjangan jabatan dimaksud bervariasi antara Rp 350.000 - Rp 1.300.000. Dalam Perpres itu disebutkan, "Tunjangan Jabatan Pustakawan diberikan setiap bulan kepada Pegawai Negeri Sipil (PNS) yang diangkat dan ditugaskan secara penuh dalam Jabatan Fungsional Pustakawan 
sesuai dengan ketentuan peraturan perundangundangan". (www.kopertis12.or.id diakses tanggal 15 Januari 2014 pukul 21.05 WIB). Dengan adanya peraturan yang mengatur tentang tunjangan fungsional pustakawan ini, maka dapat memotivasi para pegawai dalam melakukan pekerjaannya.

Demikian juga dengan kondisi kerja yang juga merupakan faktor pendukung dari motivasi kerja ektrinsik dalam rangka peningkatan kinerja pegawai di BPAD Propinsi Bengkulu. Kondisi kerja dalam hal ini meliputi suasana yang nyaman dan menyenangkan, cahaya yang cukup, jauh dari polusi dan ancaman bahaya, serta ditunjang dengan fasilitas yang lengkap. Kondisi kerja sering disebut juga dengan lingkungan kerja. Lingkungan kerja dikatakan bagus apabila dalam kondisi tertentu pegawai dapat secara optimal melakukan pekerjaannya, dengan demikian kinerja pegawai juga akan meningkat. Begitupun sebaliknya jika lingkungan kerja tidak baik maka akan menurunkan kinerja pegawai. Seiring dengan hal ini, ada pendapat yang mengatakan bahwa, "Lingkungan kerja merupakan segala sesuatu yang ada disekitar para pekerja yang dapat mempengaruhi dirinya dalam menjalankan tugas yang dibebankan", (Nitisemito, 1982:109). Lingkungan kerja dapat berupa lingkungan kerja fisik maupun hubungan kerja antar pegawai di dalam lembaga itu sendiri. Lingkungan kerja dalam suatu organisasi merupakan suatu keadaan atau kondisi dalam bekerja sehingga tercipta suasana kerja yang nyaman dan kondusif, dengan demikian peningkatan kinerja pegawai di perpustakaan akan terwujud. Lingkungan kerja dikatakan memiliki pengaruh yang kuat terhadap peningkatan kinerja pegawai.

Disamping kondisi kerja dan hubungan antar pribadi yang merupakan faktor pendukung motivasi kerja ektrinsik berikutnya adalah perhatian dari pimpinan yakni kebijaksanaan dan administrasi perpustakaan, yang meliputi semua bagian pekerjaannya atau baik buruknya pekerjaan yang dilakukan. Begitu juga dengan fungsi pimpinan sebagai manajer dalam perpustakaan yakni fungsi pengawasan (controlling), sebagaimana yang telah diungkapkan oleh ahli manajemen, bahwa fungsi manajemen menurut G.R Terry yakni: "Planning, Organizing, Actuating, Controlling". Dan ada pendapat yang berbeda dari Siagian dalam Hasibuan (2003:17), yang menyebutkan lima fungsi manajemen yaitu: "Planning, Organizing, Motivating, Controlling, Evaluating)". Seiring dengan pendapat ini menjelaskan bahwa pimpinan memiliki peranan yang penting dalam fungsi manajemen di perpustakaan khususnya dalam controlling bagi para pegawainya. Dari fungsi manajemen ini, pegawai akan diberikan jabatan yang cocok dan sesuai dengan prestasinya. Maka antara kebijaksanaan dan administrasi perpustakaan memiliki pengaruh yang signifikan dalam upaya peningkatan kinerja pegawai di BPAD Propinsi Bengkulu. Begitu juga dengan indikator berikutnya yang mendukung motivasi kerja ektrinsik pegawai dalam meningkatkan kinerjanya adalah bagaimana caranya pegawai melakukan sendiri pekerjaan yang diembankan kepadanya disamping adanya pengawasan dari pimpinan. Maksudnya pegawai bertanggungjawab terhadap pekerjaannya dan tidak meminta bantuan orang lain dalam melakukan tugasnya, namun apabila pegawai mengalami kesulitan dalam melakukan pekerjaannya maka tidak ada salahnya meminta bantuan kepada pegawai lain yang mengerti dan lebih senior.

Berkenaan dengan beberapa teori motivasi dijelaskan bahwa motivasi kerja ektrinsik yang dihubungkan dengan hasil uji yang telah diteliti, maka motivasi kerja ektrinsik berpengaruh signifikan terhadap kinerja pegawai dengan hasil $t_{\text {hitung }}$ lebih besar dari $t_{- \text {tabel }}$ ( $t_{\text {hitung }}$ $\left.4,16>t_{\text {tabel }} 1,98\right)$. Koefisien jalur yang ditunjukkan dari hasil uji motivasi kerja ektrinsik terhadap dimensi ini juga bersifat positif, berarti semakin tinggi motivasi kerja ektrinsik maka akan semakin tinggi pula kinerja pegawai di BPAD Propinsi Bengkulu.

\section{Uji F dari Stuktur Pengaruh Motivasi Kerja Terhadap Kinerja Pegawai di BPAD}

Berdasarkan hasil perhitungan analisis jalur diperoleh besaran sebagai berikut:

\section{Hasil Uji F Model}

\begin{tabular}{|lr|l|l|}
\hline Model & & $\mathbf{F}_{\text {hitung }}$ & $\mathbf{F}_{\text {tabel }}$ \\
\hline $\begin{array}{l}\text { Motivasi intrinsik dan } \\
\text { ektrinsik terhadap kinerja } \\
\text { pegawai }\end{array}$ & 157,55 & 3,10 \\
\hline
\end{tabular}

Sumber: Pengolahan Data 2014

Dari tabel $\mathrm{F}$ diperoleh nilai $\mathrm{F}_{[0,05: 2: 92]}=$ 3,10. Dalam pengujian koefisien jalur secara keseluruhan, tolak hipotesis jika $\mathrm{F}$ hitung $>\mathrm{F}$ tabel $(\alpha:(n-k-1), k)$, dalam hal lainnya terima hipotesis 
nol. Oleh karena nilai $F_{\text {hitung }}(157,55)>F_{\text {tabel }}(3,10)$ maka hipotesis nol ditolak. Dapat disimpulkan bahwa model dapat digunakan untuk menunjukkan model pengaruh motivasi intrinsik dan ektrinsik terhadap kinerja pegawai. Dengan perumusan hipotesis $\mathrm{H}_{0}$ : Tidak ada pengaruh yang signifikan antara motivasi kerja terhadap kinerja pegawai di BPAD Propinsi Bengkulu, dan $\mathrm{H}_{1}$ : Ada pengaruh yang signifikan antara motivasi kerja terhadap kinerja pegawai di BPAD Propinsi Bengkulu.

Hasil pengujian bersama-sama menunjukkan kedua dimensi yaitu motivasi kerja intrinsik dan ekstrinsik yang memiliki sembilan indikator yang berpengaruh nyata terhadap kinerja pegawai. Total pengaruh kedua dimensi yaitu motivasi kerja intrinsik dan ekstrinsik dari tabel pengaruh simultan atau uji $\mathrm{F}$ diperoleh nilai $\mathrm{F}_{[0,05: 2: 92]}=3,10$. Dalam pengujian koefisien jalur secara keseluruhan, tolak hipotesis jika $\mathrm{F}$ hitung $>$ F tabel $(\alpha:(n-k-1), k)$, dalam hal lainnya terima hipotesis nol. Oleh karena nilai $F_{\text {hitung }}(157,55)>$ $\mathrm{F}_{\text {tabel }}(3,10)$ maka hipotesis nol ditolak. Dapat disimpulkan bahwa model baik digunakan untuk menunjukkan model pengaruh motivasi intrinsik dan ektrinsik terhadap kinerja pegawai. Dari kesimpulan tersebut, maka dapat dijelaskan bahwa motivasi kerja intrinsik dan ekstrinsik dinilai mampu mempengaruhi kinerja pegawai di BPAD Propinsi Bengkulu. Hal tersebut dapat terlihat dari adanya motivasi yang positif yang diberikan pegawai di BPAD Propinsi Bengkulu.

Pegawai merupakan sumber daya manusia yang memiliki peran penting dalam upaya peningkatan kinerja perpustakaan. Pegawai yang didalamnya juga terdapat pustakawan harus memiliki motivasi kerja, baik itu motivasi kerja intrinsik maupun motivasi kerja ekstrinsik dalam meningkatkan kinerja bagi perpustakaan. Motivasi kerja intrinsik merupakan motivasi yang muncul dari dalam diri individu (pegawai) itu sendiri, sedangkan motivasi kerja ektrinsik merupakan motivasi yang muncul dari luar diri individu itu sendiri yang bersifat membangun dan akhirnya menciptakan kepuasan kerja bagi pegawai dalam melaksanakan tugasnya. Sebagaimana teori motivasi yang diungkapkan oleh Frederick Herzberg (Two Factor Theory) dimana, "motivasi dapat diukur oleh dua faktor yang menyebutkan kepuasan kerja menurut Herzberg selalu dihubungkan dengan isi pekerjaan (job content), dan ketidakpuasan dalam bekerja yang disebabkan oleh faktor lingkungan sekitar. Kepuasan dalam bekerja menurut Herzberg disebut satissfiers yang dapat juga berperan sebagai motivator atau dengan kata lain disebut inner motivation atau sering juga disebut dengan motivasi intrinsik, sedangkan ketidakpuasan (disatissfiers) disebut dengan faktor hygiene atau sering juga disebut motivasi ekstrinsik", (Hasibuan, 2003:110). Yang termasuk dalam faktor motivasi intrinsik adalah prestasi, pengakuan, pekerjaan itu sendiri, pengembangan potensi individu. Yang termasuk dalam faktor hygiene seperti gaji atau upah, kondisi kerja, kebijaksanaan dan administrasi perusahaan, hubungan antarpribadi, kualitas supervisi.

Hal ini berarti bahwa motivasi kerja intrinsik dan ektrinsik mempengaruhi dan berperan dalam menentukan dan menciptakan kinerja yang optimal bagi para pegawai dalam melaksanakan pekerjaannya khususnya di BPAD Propinsi Bengkulu. Hal ini dihubungkan dengan manfaat pengukuran kinerja bagi perpustakaan sesuai standar ISO 11620 tahun 2008 yang diungkapkan oleh Saleh (2013:2-3), "untuk mengevaluasi; untuk mengendalikan; untuk menganggarkan; untuk memotivasi; untuk merayakan; untuk belajar; dan untuk mengembangkan)". Dalam beberapa teori motivasi dijelaskan yang dihubungkan dengan hasil uji yang telah diteliti dan sesuai standar ISO 11620 tahun 2008, maka motivasi kerja berpengaruh signifikan terhadap kinerja pegawai di BPAD Propinsi Bengkulu dengan hasil nilai $F_{\text {hitung }}(157,55)>F_{\text {tabel }}(3,10)$. Dengan koefisien jalur yang positif dan dapat disimpulkan bahwa semakin tinggi motivasi kerja maka semakin tinggi pula kinerja pegawai.

\section{Simpulan}

Pengaruh motivasi kerja intrinsik dan ektrinsik terhadap kinerja pegawai di BPAD Propinsi Bengkulu secara simultan terdapat pengaruh yang signifikan dengan ditunjukkan oleh hasil perhitungan $f_{\text {hitung }}>f_{\text {tabel, }}$ serta dengan koefisien jalur yang positif, artinya semakin tinggi motivasi kerja intrinsik dan ektrinsik maka semakin tinggi pula kinerja pegawai. Secara parsial motivasi kerja intrinsik dan ektrinsik juga berpengaruh secara signifikan terhadap beberapa dimensi dari variabel kinerja pegawai yakni terhadap ketersediaan sumberdaya dan layanan, penggunaan sumberdaya dan layanan, efisiensi, 
serta potensi dan pengembangan yang ditunjukkan dengan hasil $t_{\text {hitung }}>t_{\text {tabel. }}$.

\section{DAFTAR PUSTAKA}

Hasibuan, Malayu S.,P. 2003. Organisasi dan
Motivasi
Dasar
Peningkatan

Produktivitas. Jakarta: Bumi Aksara.

Mangkunegara, A.A. Anwar Prabu. 2001. Manajemen Sumber Daya Manusia Perusahaan. Bandung: Remaja Rosdakarya.

Nitisemito, Alex S. 1996. Manajemen Personalia: Manajemen Sumber Daya Manusia. Jakarta: Ghalia Indonesia.

Riva'i, Veithzal. 2008. Manajemen Sumber Daya Manusia untuk Perusahaan. Jakarta: Raja Grafindo Persada.

Saleh, Abdul Rahman. 2013. Pengukuran Indikator Kinerja Menurut ISO 11620:2008. Bedah Standar ISO 11620:2008 Kerjasama antara Badan Standarisasi Nasional dengan Perpustakaan Nasional RI, Tanggal 31 Oktober 2013. Jakarta: Badan Standarisasi Nasional.

Siagian, Sondang. 2004. Teori Motivasi dan Aplikasinya. Jakarta: Rineka Cipta. 